\title{
With Spanish, Guaraní lives: a sociolinguistic analysis of bilingual education in Paraguay
}

Hiroshi Ito

\begin{abstract}
Through interviews with Paraguayan parents, teachers, intellectuals, and policy makers, this paper examines why the implementation of Guaraní-Spanish bilingual education has been a struggle in Paraguay. The findings of the research include: 1) ideological and attitudinal gaps toward Guaraní and Spanish between the political level (i.e., policy makers and intellectuals) and the operational level (i.e., parents and teachers); 2) insufficient and/or inadequate Guaraní-Spanish bilingual teacher training; and 3) the different interpretations and uses of the terms pure Guaraní (also called academic Guaraní) and Jopará (i.e., colloquial Guaraní with mixed elements of Spanish) between policy makers and intellectuals, and the subsequent issue of standardizing Guaraní that arises from these mixed interpretations. Suggestions are made to carve out a space wherein we might imagine an adequate implementation of bilingual education.
\end{abstract}

Keywords: Bilingual education policy, Language ideologies and attitudes, Diglossia, Guaraní, Paraguay

\section{Introduction}

The sociopolitical linguistic landscape in Paraguay is unique, complex, and even contradictory. Unlike many languages indigenous to Latin America, the bulk of which have disappeared since European colonization, the Guaraní language has survived for centuries across various contexts and became an official language of Paraguay in 1992. ${ }^{a}$ While other indigenous languages in the region have also gained legitimate status, most notably Quechua and Aymara in Peru and Bolivia, their use is largely limited to indigenous populations (Gynan 2007). By contrast, Guaraní is spoken by the majority (over $80 \%$ ) of Paraguayans, , most of whom are mestizos, with a mixture of European and Amerindian ancestry. Despite Guaranís widespread use and official status, Spanish is dominant in official domains such as public administration, schooling, mass media, business, and commerce. In the context of education, although the majority of Paraguayan children, especially in rural areas, speak Guaraní natively, the language of instruction is predominantly Spanish. With Spanish being the dominant language in official domains, it is essential for Paraguayan

Correspondence: h.ito@unesco.org

7 Place de Fontenoy, Paris 75007, France children to learn Spanish. Yet, without Guaraní in the classroom, it is difficult for Guaraní-speaking children to learn Spanish and other academic content taught in Spanish as well as for the teachers to teach. Indeed, among language experts, it is generally agreed that education should be received in learners' mother tongues to best enhance overall academic performance as well as second language acquisition (Benson 2002; Brisk 2006; Bühmann and Trudell 2008; Cummins 2009; He 2012; Trudell 2012). Several attempts have been made to implement Guaraní-Spanish bilingual education at the policy level, but these attempts have largely failed-Paraguayans are not bilingually educated yet for a variety of reasons.

Through interviews with 39 Paraguayan adults (16 parents, 16 teachers, 3 intellectuals, and 4 policy makers), this paper examines issues undermining the implementation of Guaraní-Spanish bilingual education in Paraguayan classrooms. With these issues in mind, a context is theorized wherein we might imagine an adequate implementation of Guaraní-Spanish bilingual education. To contextualize interviews, I provide a historical background, explain language ideologies and diglossia, discuss instrumental and integrative values of language, and review previous relevant studies in the following sections preceding my own analysis. 


\section{Historical background}

This section describes how Guaraní has survived for centuries across various contexts, through Spanish colonization and social exclusion, to finally become an official language. As depicted below, a number of factors and historical events have influenced Paraguay's language policies as well as Guaraní's survival.

\section{Possible reasons for the survival of Guarani}

There are several explanations for the survival of Guaraní, one of which concerns Paraguayan geography. The country is surrounded by the Paraguayan and the Parana Rivers, running from the Atlantic to the eastern foothills of the Andes. This geographical factor has helped Paraguay avoid external invasions, massive immigration, and assimilative cultural influences, though the use of Guaraní has not been solely limited within the territories between the two rivers (Fogelquist 1950).

Another possible reason for the language's survival is through the phenomenon of "mestizaje," a blending of Spanish and Guaraní roots and culture as a result of unions between Spanish males and Guaraní females. In the initial period of Spanish settlement, Guaraní rooted itself as the principal language for the majority of the Paraguayan population as the mestizos born between Spanish fathers and indigenous mothers grew up with the language of the mother, Guaraní. In 1570, while the population of pure Spaniards was only 300, that of mestizos was 10,000 (Gómez 2006).

Concerning language and culture, most indigenous speakers within Latin America have had to do one of two things: (1) turn from their roots to culturally and linguistically assimilate into the dominant sociolinguistic hegemony or (2) cling to their roots and become culturally and linguistically isolated. Paraguayans have had to do neither. Having European blood, the Guaraní-speaking mestizos were regarded as more "white" than "indigenous," and therefore, they were not discriminated against as much as other indigenous language speakers in Latin America (Gómez 2006). In fact, Guaraní has become very much a part of the dominant sociolinguistic hegemony as the language is widely spoken even in the capital of Asunción and amongst the upper class.

Apart from Paraguayan geography and mestizaje, the contribution of Franciscan and Jesuit missionaries is invariably noted as a critical element in the survival of Guaraní. The Franciscans initiated their work in 1575, constructing their "Reducciones" (Christian mission villages) in the territory near Asunción. In the villages, Guaraní was the dominant language. The Jesuits arrived in Paraguay in 1587 and also founded Reducciónes (Gómez 2006). The Jesuits studied and created a written form of Guaraní and made it the only official language in the Jesuit provinces. All communication was conducted exclusively in Guaraní: teaching, religious practice, administration, and literary work (Villagra-Batoux 2002). The presence of the Franciscans and the Jesuits was a major linguistic bulwark for supporting the use of Guaraní rather than Spanish.

\section{Early political stances toward Guaraní}

The political attitude toward Guaraní has fluctuated throughout Paraguayan history, largely dependent on ruling political leaders and prevailing sociopolitical contexts. Following the expulsion of the Jesuits in 1767, the Paraguayan government declared the enactment of “castellanización” (Spanishization/Hispanization). After independence from Spain in 1811, Fernando de la Mora, a political leader who had been inspired by a Rousseauian Enlightenment education, advocated for Spanish as the sole language of instruction. However, when the first President of Paraguay José Gaspar Rodríguez de Francia came to office in 1814, he expelled many Spanish-speaking elites, including Fernando de la Mora, and promoted primary education in Guaraní in order to unite the nation and secure his dictatorship (Cooney 1983). On the contrary, Carlos Antonio López, the next dictator and the first president after the 1844 constitution, reinstated Spanish as the official language in education and made obligatory the printing of all publications in Spanish. He considered Spanish language acquisition essential for Paraguay to introduce modern culture and advance national development, while he regarded Guaraní as a useless barbaric language (Villagra-Batoux 2002).

The sociolinguistic landscape changed during the War of the Triple Alliance against Argentina, Brazil and Uruguay from 1864 to 1870 . The significance of Guaraní as a symbol of national identity and an information tool for transmitting secret orders in the war was reexamined. After the War of the Triple Alliance, the language policy shifted, and Guaraní was reframed as an obstacle to national development. In the postwar era, children in Asunción were prohibited to learn Guaraní at school (Rubin 1968). It was during the Chaco War against Bolivia in 1932-1935 that Guaraní once again attracted political attention. As was the case with the War of the Triple Alliance, the language was appreciated as a symbol of national identity as well as a strategic tool (Engelbrecht and Ortiz 1983). After the Chaco War, Paraguay's language policies continued to vary, depending on the political regime and conditions.

\section{Language policies from Stroessner's dictatorship to the present day}

During the Stroessner administration from 1954 through 1989, the Guaraní language was considered a national symbol of unification and patriotism. However, the language policy did not intend to promote Guaraní politically. Although the National Constitution in 1967 declared both Guaraní and Spanish as co-national 
languages, only Spanish received the prestigious status of an official language (Republic of Paraguay 1967). Guaraní was still discriminated against as it was excluded from administrative, judicial, and commercial spheres. In 1973, the Stroessner administration enacted transitional bilingual education called the Programa de Educación Bilingüe (Bilingual Education Program), which recommended oral instruction in Guaraní in the first cycle of primary education in rural areas. However, it was in reality a program of hispanicizing Guaraní monolingual children: it intended to quickly teach students Spanish which then became the principal language of learning (Corvalán 1989; Engelbrecht and Ortiz 1983; Gómez 2007; Pic-Gillard 2004).

After the fall of the Stroessner government in 1989, as part of the process of democratization, along with Spanish, Guaraní became recognized as an official language by the New National Constitution in 1992. The New Educational Reform of the same year requires the teaching of both Guaraní and Spanish in school. Later, Guaraní established its position as an official language by means of the Plan de Educación Bilingüe (Bilingual Education Plan) in 1994 and the Ley General de Educación (General Education Law) in 1998. Unlike the Bilingual Education Program in the 1970s, the 1994 Bilingual Education Plan aims to "bilingualize" instead of "hispanicize" all the Paraguayan population between 15 and 35 years old by 2020. The General Education Law assures that students receive education in their mother tongue. Paraguay's Ministry of Education recognized that Spanish submersion or transitional programs for monolingual Guaraní students were ineffective, exacerbating problems of absenteeism and illiteracy (Gynan 1999).

Nonetheless, Paraguayan public education today has not much changed from decades past. As López (2009) describes, the national educational system is only partially bilingual and Spanish remains the predominant language of instruction. Pic-Gillard (2004) warns against the bilingual model proposed by Paraguay's Ministry of Education being similar to the transitional bilingual model in 1973: teachers as well as parents continue to privilege and teach Spanish over Guaraní at school and home. Furthermore, many seem to believe that Paraguay should abandon Guaraní and focus on learning Spanish as a language of wider communication for Paraguay's national development (Centurión 2004).

The issue is that the bilingual language policy, coupled with Spanish-only language practice in official realms, has failed to improve either the quality of education or Spanish proficiency (Pic-Gillard 2004). Despite the country's $90 \%$ net enrolment rate at the primary education level (UNESCO, 2011), its dropout rate is high and less than $30 \%$ of students who enrol in the first grade of primary school complete high school due to linguistic as well as socioeconomic reasons (Peralta, Misiego, and Prieto 2011). This fact raises an interesting pair of interrelated questions: Do Guaraní speakers drop out of schools because the education system fails to properly teach them Spanish? Or, do they drop out because the education system fails to properly teach them in their native tongue? If, as Gynan (2007) argues, Paraguay's high rates of absenteeism and early dropout are attributed to the dominant use of Spanish in the classroom (e.g., literacy instruction in Spanish), why do teachers not use more Guaraní as the language of instruction? Why, despite the officialization of Guaraní and the introduction of bilingual education, does Guaraní continue to have a low profile in the education system? Some scholars speculate the existence of an underlying ideology-Spanish is socioeconomically more important than Guaraní-that thwarts the use of Guaraní in classroom (Caballero 2008; Hauck 2009; Ito 2010; Mortimer 2006). This language ideology can be better understood through the lens of diglossia, the existence of two languages whereby one has a more privileged function in certain domains.

\section{Literature review}

This section reviews relevant linguistic theoretical literature and previous research studies on Paraguay's bilingual education system to situate my work with the larger context of language policy in education. I first touch upon the theories of diglossia, instrumental and integrative values of language, language legitimation and institutiona lization, and second language acquisition (SLA) theory before reviewing other researchers' prior studies.

\section{Diglossia $^{c}$}

In the theory of diglossia, the language with more formal functions and higher prestige is called the language of high variety $(\mathrm{H})$ as opposed to the language of low variety (L), with informal functions and lower prestige. For instance, $\mathrm{H}$ is used in public administration, schooling, mass media, business, and commerce, while $\mathrm{L}$ is used within the context of home and family, social and cultural activities in the community, and correspondence with relations and friends (Baker 2006). Given that $\mathrm{H}$ is used in official domains, the speakers of $\mathrm{H}$ benefit socioeconomically from their ability to speak that language while the speakers of $\mathrm{L}$ are disadvantaged. Consequently, the speakers of L start favoring and learning $\mathrm{H}$, usually to the detriment of L.

Paraguay's bilingual situation is diglossic with Spanish being $\mathrm{H}$ and Guaraní being L (Fishman 1967; Hudson 2002); albeit Guaraní has obtained the same official status as Spanish. Hence, Spanish speakers will continue to use Spanish in official contexts while Guaraní speakers will strive to learn and support Spanish as well. These circular processes from diglossia to ideology and vice versa 
through language use and attitudes perpetuate asymmetrical power relations between $\mathrm{H}$, Spanish (and its speakers) and L, Guaraní (and its speakers). How do we interpret this peculiar diglossia in the context of the Paraguayan sociolinguistic climate?

\section{Instrumental and integrative values of languages}

There are two language values that may influence language use and attitudes: instrumental value and integrative value. These language values are often unconscious. Although these two terms are not easily defined, the instrumental value of language is largely socioeconomic, while integrative value is principally sociocultural. As Brisk $(2006,83)$ explains, "[I]ndividuals with integrative motivation want to learn the language to socialize and share in the culture of the speakers of that language. Learners with instrumental motivation have practical reasons for learning language." Yet, these definitions are variable, and the boundary between them is often unclear. For instance, Wright $(2004,5)$ argues that, while indigenous languages "can still rightly be regarded as carriers of traditional affect, it would be a serious distortion to view them as the sole repositories of emotional attachment, or social and cultural allegiance." In other words, indigenous languages (e.g., Guaraní) can have instrumental values. In Latin America, for example, despite its sociopolitical prestige and functions, former colonial languages, such as Spanish and Portuguese, may already be detached from the colonial context in many respects, possibly because Latin America gained independence in the early nineteenth century and the majority of Latin Americans have spoken the former colonial languages for generations. That is to say, Spanish and Portuguese have become engrained in Latin American cultures. Likewise, indigenous languages, especially those with millions of speakers like Guaraní, can possess instrumental value. Wright $(2004,6)$ argues that indigenous languages "are obviously languages of commercial interaction, intellectual debate, and social aspiration within their own speech communities. There is also the commercial utility of multilingualism to consider both within and across speech." It is, therefore, inappropriate to claim that only some languages have instrumental value, whereas other languages have integrative values because languages can, and usually do, possess both values.

Despite its potential instrumental value, Paraguayans tend to disassociate Guaraní with socioeconomic development because Guaraní monolinguals are often academically and socioeconomically disadvantaged. This is a typical argument in the debate over Guaranís importance. While many Guaraní proponents tend to emphasize the language's integrative value as a symbol of national identity, Guaraní opponents point out its lack of instrumental value (Centurión 2004). As the Japan International Cooperation Agency (2004) reports, many Paraguayan parents and teachers in both rural and urban areas feel that education in Guaraní is inferior to education in Spanish. Parents are particularly concerned that learning Guaraní or learning in Guaraní could be detrimental to Spanish language acquisition, which will disadvantage their children educationally and socioeconomically. This suggests their preference for languages with instrumental value over languages with integrative value. In the context of Paraguay, Spanish's instrumental value over Guaraní has perpetuated Spanish's superordination, despite Paraguayans' cultural affinity toward Guaraní.

\section{Legitimation and institutionalization of language}

Legitimation of language refers to giving a language legal status as part of language policy, while institutionalization of language is to translate the language policy into practice. The aforesaid Quechua and Aymara, for example, have been granted official status and thus are legitimized but have not been institutionalized. May (2008) explains that for a language to be institutionalized, it has to be perceived as a common language used in a wide range of sociocultural contexts and both official and unofficial domains. French in Canada is an example of the institutionalization of a language. What about Guaraní in Paraguay? Guaraní has been given legitimate status as an official language. Given its widespread use and official status, some say that Guaraní has become institutionalized while others say that the language remains to be institutionalized. From my perspective, Guaraní is "stuck" somewhere between legitimation and institutionalization. As the diglossia in Paraguay reveals, Guaraní has not yet been fully used in official domains. Despite Guaranís government-recognized status and the enactment of Guaraní-Spanish bilingual education plan, governmental documents and textbooks are still predominantly written in Spanish. According to May's definition, Guaraní has not become institutionalized.

\section{Second language acquisition (SLA) theory}

As is the case with the issue of Spanish-English bilingual education in the United States, bilingualism is often viewed as a problem rather than a resource (Ruíz; 1984; Brisk 2006). Immigrants to the United States, for example, often decide not to teach their children their native languages, and talk to them in English out of concern that the knowledge of their native language will be detrimental to the children's English acquisition (Brisk 2006; Tse 1999; Wiley 2005). Tse (2001) states that this assumption of a first language competency preventing the acquisition of a second "is based upon the widely held belief that knowing one language will hamper the learning of a second. This myth is based perhaps on the popular notion that individuals have a limited capacity for knowing language" (45). She continues to argue that "many believe in the myth that simultaneous 
development of two languages will result in inferior learning of both, the proposed solution is for students to forget or at least put aside" (71) their native language while learning their second language. Conversely, SLA theory recommends the use of the mother tongue as the language of instruction for enhancing the academic performance as well as second language acquisition (Benson 2002; Brisk 2006; Bühmann and Trudell 2008; Cummins 2009; He 2012; Trudell 2012). This theory gained popularity through a series of Cummins' works in the early 1980s, and has been influential until now. For instance, Cummins and Scheter $(2003,6)$ explain that instruction through native language is "promoting overall conceptual development and other forms of academic knowledge that are transferable across languages." The idea that education in one's native language enhances academic performance and second language acquisition is not new. In Paraguay, Cummins' bilingual theory in support of education in one's native language once grew popular in the mid-1990s (Gynan 2005). Yet, the theory's popularity soon diminished for various reasons, one of which resulted from the theory failing to convince Paraguayans how education in one's native language would benefit them socioeconomically.

\section{Previous studies}

Several scholars, including Rubin (1968), Choi (2005), García (2005), and Gynan (2005), have conducted empirical sociolinguistic research in Paraguay. Rubin's (1968) qualitative study analyzed language use and attitudes, such as loyalty and pride, through questionnaires and interviews in Luque (a town located approximately ten miles from Asunción) and Itapuami (one of the suburban areas of Luque). Rubin noted that the choice of language depended upon the situation at hand. If the location was rural or the situation was informal, the language choice was Guaraní. For instance, none of the participants in Itapuami used Spanish when they spoke with their spouses or grandparents or drank tea with their friends. On the contrary, if the situation was formal, the language choice was Spanish. Likewise, if the relationship was not intimate, the language choice was Spanish. According to Rubin, there were certain social identities that required formal behavior, and thus the use of Spanish in some situations such as patient-doctor relationships and studentteacher relationships was the norm. Even in Itapuami where Guaraní was predominantly used in most situations, 37 out of 40 participants claimed that they spoke Spanish with teachers. Rubin felt "the extraordinary pressure on students and teachers to use Spanish in the school. Teachers try to insist on the use of Spanish at all times even in rural areas" (104). Rubin's study indicates Paraguayans' ambivalent feelings toward Guaraní with a refusal and a feeling of love being mixed, while they esteem Spanish. Her study depicts the diglossic reality present in Paraguay.
In his longitudinal research on the sociolinguistic situation in Paraguay, Gynan (2005) analysed the shift of Guaraní and Spanish language use and attitudes between 1995 and 2001. He observed that Paraguayans developed more positive attitudes toward Guaraní and bilingualism between 1995 and 2001 as a result of the officialization of Guaraní in 1992 and the implementation of GuaraníSpanish bilingual education that started in 1994. For instance, a higher percentage of the research sample population in 2001 claimed that children should develop literacy in their native language first, which is "a consequence of a shift in the attitude toward Guaraní literacy, which was notably lower than for Spanish in 1995, and which by 2001 was equal to that of Spanish" (27). On the contrary, the studies of Choi (2005) and García (2005) show that Paraguayans have increasingly come to favor Spanish over Guaraní.

To determine this, Choi (2005) conducted a longitudinal study from 2000 to 2001 that compared her data to Rubin's data from 1960 to 1961 in the same location (i.e., Luque and Itapuami). Choi's study suggested that while preference for Spanish only and Guaraní only declined, and the preference for both languages in turn notably increased, the promotion of bilingualism came along with the loss of Guaraní and the increased use of Spanish, a phenomenon "observed in almost all of the situations and types of interactions examined in this study" (242). Despite some advancement of Guaraní, she argues, Spanish maintains its dominant position in administrative and educational functions. Even in familiar and informal settings, she concludes, more Paraguayans are now showing preference for Spanish.

García's (2005) research also indicates that the vast majority of her sample population considered Spanish to be more important than Guaraní for socioeconomic reasons. Her research attempts to answer the question of whether Paraguayans "still compartmentalize language use" (i.e., the different use of Spanish and Guaraní according to domains) (333). She interviewed 27 families, including parents and their children, and reported that 11 families gave Spanish a higher status than Guaraní, but none of them claimed that Guaraní is more important than Spanish, though some parents believe that Guaraní is also important because it is implemented in the school system. García concluded her research by stating that some "parents follow diglossic theory, favoring the prestigious language of Spanish over Guaraní. Diglossia seems to be present at the societal level of beliefs for the majority of parents" (340).

The above-cited literature illustrates that while Paraguayans may have "more" positive attitudes toward Guaraní now due to the officialization of Guaraní and the introduction of Guaraní-Spanish bilingual education in the early 1990s, they may still have "even more" positive attitudes toward 
Spanish because Spanish remains dominant in official domains and is considered socioeconomically more beneficial that Guaraní.

Given its official status and the introduction of GuaraníSpanish bilingual education, however, I argue that Guaraní is privileged and receives political support at least to some extent. Then, how has the Guaraní-Spanish bilingual policy and education been thwarted? How do Paraguayan parents, teachers, intellectuals, and policy makers feel differently about Guaraní and Spanish, and the bilingual education policy? What are the technical and practical as well as ideological issues that may have hindered an adequate implementation of Guaraní-Spanish bilingual education? It is in this context and within this framework that my research was conducted and my data were analyzed.

\section{Research design}

For the purpose of my sociolinguistic research, interviews were employed, as sociolinguistic analysis requires individuals' opinions that may reflect their attitudes toward languages. Parents, teachers, intellectuals, and policy makers were selected because they form a sociopolitical pyramid in education from the policy level to the operational level. Language policies are decided at the policy level, rendering opinions of officials from the Ministry of Education very important. Intellectuals are mediators that play a critical role in transmitting and/or translating information from the policy level to the public (e.g., parents and teachers) where language policy is actually applied. At the policy level, Guaraní became an official language and Guaraní-Spanish bilingual education was introduced in the 1990s. At the operational level, however, bilingual policy has often been invisible without having materialized properly. In order to examine the process of how language policy has been transmitted (or not) to the public, interviews with actors at each level are considered essential, but no extant empirical research includes all of them.

I conducted interviews with 39 individuals: 16 parents and 16 teachers from three schools in the Department of Central ${ }^{\mathrm{d}}$ and three schools in the Department of Caaguazú ${ }^{\mathrm{e}}$ along with three intellectuals and four policy makers in Asunción. All of the policy makers and intellectuals are experts and specialists with expertise in language-of-instruction policy/practice and bilingual education. The policy makers interviewed were Gloria Franco, Bilingual Education Specialist; Luz Aranda, Early Childhood Education Expert; Juan Martínez, Education Supervisor and Nancy Benitez, Director of Curriculum, Evaluation, and Orientation. All of them were officials of the Ministry of Education. The intellectuals interviewed were: José Silvero, Professor of Philosophy at the National University of Asunción; David Galeano, Director of ATENEO (Institute of Culture and the
Guaraní Language); and Fátima Rodríguez, Journalist. While pilot studies were conducted through observations and questionnaires during my stay in Paraguay between 2004 and 2007, ${ }^{\mathrm{f}}$ the interviews included in this paper took place from February to March 2010. The interview questions were as follows:

1. Which language do you speak to your children at home and why? If you do not have children, which language would you teach them and why?

2. Have you noticed any changes in school or in class since the officialization of Guaraní in 1992 and the introduction of bilingual education in 1994 ?

3. How do you think Paraguayan children in rural areas can learn Spanish best?

4. What is your opinion about "pure Guaraní" and "Jopará"?

The first question concerning which language is spoken to children was intended to examine the language attitudes of the interviewees. With the second question, I sought to examine how the process of the government's language-of-instruction policy and its implementation has been perceived. The third question was posed to explore how children in rural areas who have no exposure to Spanish should learn to use the language properly because as Galeano (2002) argues, acquiring both Guaraní and Spanish competencies would be essential for the bilingual education policy to be implemented adequately. The last question addresses the issue of normalization or standardization of the Guaraní language, which has been a matter of urgency in its implementation in formal schooling. The use of pure Guaraní (also called scientific or academic Guaraní) or Jopará (colloquial Guaraní with mixed elements of Spanish) as the language of instruction has been discussed among policy makers and intellectuals (Corvalán 2005; Valadez 2002; Mortimer 2006; García 2011) but no consensus has been reached. These questions were developed based on my pilot studies as well as consultations with various scholars in the field and were adapted as necessary. The interviews were conducted in both Guaraní and Spanish.

\section{Results}

With respect to language spoken at home, Spanish is favored, as it is positioned as instrumental in improving children's education. Even in Caaguazú, where Guaraní is dominant, half of the participants reported that they talk to their children in Spanish at home, 21.4\% reported using Guaraní and the rest reported using both languages. A parent in Caaguazú reported: "At home, Spanish is intentionally spoken in order for my children to learn and think in Spanish and to better understand the information [presented to them]. If children only speak Guaraní, they 
will struggle to understand educational content because the majority [of the content] is in Spanish." This comment suggests that Spanish acquisition is crucial to academic and thus social success and is pursued even at the cost of the native language. A teacher in Caaguazú emphasized the significance of Spanish by stating that Spanish is spoken in the office, in the university, and in other countries. "Dominance of Spanish in national and international domains leaves Guaraní fewer possibilities."

Benitez confessed a dilemma of this diglossic situation. "The value of Spanish in Paraguayan society is indisputable. In language policy, both [Spanish and Guaraní] are important, but socially, Spanish has the advantage." She regards one of Spanish's notable advantages is that all written documents are in Spanish. On the other hand, "Guaraní is disadvantaged because it lacks a writing system. This creates a diglossic situation." " Martínez also showed a concern about this diglossia: "There is no equity between Spanish and Guaraní, despite the linguistic reality [that Guaraní is demographically dominant]." Rodríguez explained the diglossic phenomena due to the relationship between language and success. "Today, there are Paraguayans who believe that Guaraní hinders Spanish acquisition, but they never argue that Spanish hinders Guaraní acquisition. It is a question of increasing one's probability of success. That is to say, good use of Spanish is a requisite for finding a job, but that of Guaraní is not." These statements were made based on individuals' recognition of the instrumental value of Spanish for its geographic prevalence (i.e., cities and foreign countries) and its use in important domains (e.g., school and work). As Benitez affirmed, the significance of Guaraní as well as Spanish is recognized at the policy level; however, the bilingual language policy has not been put into practice at the operational level arguably because Spanish surpasses Guaraní in instrumental value.

In regards to the school setting, some interviewees' answers reflected positive views toward the policy change since the officialization of Guaraní. A parent in Central, for example, commented that Guaraní is given more importance now. "When I entered school, speaking Guaraní was prohibited and all the classes were taught in Spanish. Guaraní speakers were discriminated against in urban areas. Now, all the students from $1^{\text {st }}$ grade to $12^{\text {th }}$ grade learn Guaraní." The policy change also appears beneficial with regard to children's psychosocial well-being. A teacher in Caaguazú reported that students seem more open and more comfortable in the classroom now. "Students are more participatory and more expressive because their native language is used."

Some interviewees, however, feel that these changes are superficial. Franco, for example, stated, "If foreign scholars come to Paraguay and read the documents about bilingual education, they will think that bilingual education has been accomplished. Yet, in reality, very little or nothing has been done." She explained one of the reasons why bilingual education has failed. "No one prepared teachers to be bilingual educators. Teachers do not respect the mother tongue of students and they teach in Spanish as they used to do because they find it easier to continue what they have been doing. That is why bilingual education has not yet been implemented, though it has been almost 20 years since the officialization of Guaraní."

Concerning rural children's Spanish acquisition, nearly half of the parents and teachers claimed that children in rural areas should learn Spanish at school. A teacher in Central, for example, claimed that Spanish should be taught only in school because Spanish is not spoken at home in rural areas. Many parents and teachers seemed to believe that the language of instruction should be exclusively Spanish in order for rural students to learn the Spanish language effectively. A teacher in Caaguazú said that teachers should teach all classes only in Spanish. Also, some parents and teachers announced that parents should talk to their children in Spanish at home. A teacher in Caaguazú remarked that parents have to talk to their children in Spanish at home as well because it is not enough to learn Spanish only in school.

All the policy makers and intellectuals emphasized the urgent necessity of an adequate teacher training program for teaching Spanish as a second language as a prerequisite for the implementation of truly bilingual education. Benitez, for example, expressed her concern that teachers lack Spanish proficiency. "Teachers have to teach Spanish, but many do not have Spanish competency." Galeano also stated that one of the serious problems in Paraguayan education is how to teach Spanish. He said that teachers should learn the methods of teaching Spanish as a second language because the language structures and rules of Spanish and Guaraní are very different. According to Galeano, Guaraní-speaking children naturally attempt to apply the logic of Guaraní when they learn and speak Spanish, but they often have difficulty in doing so due to the linguistic differences between Spanish and Guaraní. For example, "I walk" in Guaraní is aguata and "you walk" is reguata. The prefix of the verb conjugates according to the subject. On the other hand, "I walk" in Spanish is camino and "you walk" is caminas. The suffix of the verb conjugates according to the subject. Galeano expressed these structural differences between Guaraní and Spanish as "a bomb in the head" and warned that without training teachers in second language acquisition, Guaraní-speaking children will not learn Spanish properly, and Guaraní will be blamed for an inadequate Spanish acquisition. Silvelo told me that teacher training and bilingualism are the two interrelated critical issues that have been problematic in 
Paraguayan education in the last two hundred years, and the government has to deal with this vicious cycle through training bilingual teachers.

As to the issue of pure Guaraní and Jopará, the majority of participants did not express positive views of pure Guaraní. For instance, one participant in Caaguazú claimed that pure Guaraní should not be taught in school because it is not understood. Another said that pure Guaraní is useless because it is not used in daily life. All the policy makers and intellectuals interviewed, except one, held negative impressions of pure Guaraní. For example, Franco explains, "With Spanish, Guaraní lives. Pure Guaraní does not have a future. Jopará must be used for communication, including writing." Benitez also denied the use of pure Guaraní and suggested the use of Jopará in school. "We have to standardize Guaraní within pedagogical environments, but this does not refer to [language] purity. Pure Guaraní is not useful and is problematic. Children understand Jopará better." She showed me a Guaraní phrase Asumakua (I know how to add) in a Mathematics book. "Suma" is a loan word from Spanish sumar (add). As observed in this example, Paraguay's Ministry of Education uses Jopará (Spanish loan words in Guaraní).

Galeano, while recognizing the inevitability of Spanish loan words, criticized the way the Ministry of Education uses distorted and often unnecessary loan words. "In Guaraní, 'I will go to school' is Ahata mbo'ehaope, but the textbook published by the Ministry of Education reads Ahata eskuelape." He argued that this phrasing is problematic for at least two reasons. One is that they do not use the Guaraní word for school, mbo'ehao, though the word already exists in Guaraní. Unlike loan words, such as the Internet or TV, the word for school is selfexplanatory in Guaraní, meaning mbo'e (teaching) hao (box). The other reasons is that when words are borrowed from Spanish, they are often distorted, therefore distorting both languages. For example, the Spanish word for school, escuela, when borrowed, become eskuela, instead of escuela. Thus, he is concerned about what he calls "contamination" of the Spanish language as well as the scapegoating of the Guaraní language in children's improper acquisition of Spanish. When a form of Jopará uses too many Spanish loanwords, it contributes more to the diglossic situation rather than staying relevant to the contemporary way that people use the Guaraní language.

Even more problematic, however, may be the term Jopará itself, which is interpreted and used in different ways. Galeano seemed to regard the term Jopará as the Guaraní invented by the Ministry of Education. He criticized the Ministry of Education for using Guaraní that is not used by people (e.g., the use of the term eskuela instead of mbo'e hao $)$. On the other hand, Benitez used the terms Jopará and Spanish loan words interchangeably. For Benitez, the term eskuela is Jopará as well as Spanish loan words. The use of terms that are interpreted in different ways complicates the discussion of language issues in Paraguay. ${ }^{\mathrm{h}}$

The findings can be summarized as follows Table 1:

\section{Conclusion}

This research helps articulate some of the multilayered issues that may affect an adequate implementation of Guaraní-Spanish bilingual education: 1) ideological and attitudinal gaps towards Guaraní and Spanish that may fragment Paraguay's language policy between the policy level (i.e., policy makers and intellectuals) and the operational level (i.e., parents and teachers); 2) insufficient and inadequate bilingual teacher training; and 3) different interpretations and uses of pure Guaraní and Jopará between policy makers and intellectuals, and the subsequent issue of standardizing Jopará.

Regarding the ideological and attitudinal gaps between the policy level and the operational level, while policy makers and intellectuals support Guaraní as the language of instruction and the Guaraní-Spanish bilingual policy, parents and teachers tend to favor Spanish over Guaraní in part because the instrumental value of Spanish is considered to surpass that of Guaraní. In practice, even after the introduction of Guaraní-Spanish bilingual education, teachers instruct their students in Spanish at school and parents talk to their children at home in Spanish. Thus, despite the official recognition of Guaraní at the policy level, bilingual education has not been adequately implemented at the operational level as Spanish

\section{Table 1 Summary of the Findings}

\begin{tabular}{c} 
Question \\
\hline $1 \quad \begin{array}{l}\text { Despite the government's recognition of Guaraní at the policy level, Spanish is preferred among parents and teachers because of the } \\
\text { perceived instrumental value of Spanish. }\end{array}$ \\
$\begin{array}{l}\text { Despite policy change that supports Guaraní, the change seems superficial. In essence, truly bilingual education has not yet been } \\
\text { implemented at the operational level as Spanish continues as the dominant language of instruction. }\end{array}$ \\
$\begin{array}{l}\text { Parents and teachers suggested the use/teaching of Spanish at home and school in part because they believe that the use of Guaraní } \\
\text { could be detrimental to Spanish acquisition. Policy makers and intellectuals emphasized the urgent necessity of bilingual teacher training. } \\
\text { The majority of participants (i.e., parents, teachers, intellectuals, and policy makers) expressed negative views towards pure Guaraní and } \\
\text { suggested the use of Jopará. Yet, the term Jopará seemed to be interpreted differently among policy makers and intellectuals. }\end{array}$
\end{tabular}


is preferred to Guaraní by parents and teachers due to the instrumental value of Spanish over Guaraní and Spanish remains the dominant language of instruction.

Many parents and teachers, especially in rural areas, are concerned about their children's and students' Spanish acquisition. They seem to believe that the use of Guaraní at home or school may impede children's acquisition of Spanish and may negatively impact their academic performance, despite the general agreement among language experts that education should be received in learners' mother tongues to best enhance overall academic performance as well as second language acquisition. Bilingual teacher training which includes the study of second language acquisition and other language learning theories will be key for an adequate implementation of GuaraníSpanish bilingual education in Paraguay. Bilingually trained teachers with knowledge of second language acquisition theories may help reeducate parents through school meetings and community programs about the benefits of learning first in one's native language before acquiring proficiency in a second language and of the importance of parental roles in proper language development.

Beyond the operational level, an issue that disturbs the policy transmission between policy makers and intellectuals involves the different interpretations and uses of Jopará, which has been little discussed in previous studies. Both policy makers and intellectuals understand the advantage of Jopará or Spanish loan words and agree upon the use of Jopará as the language of instruction while denying the use or even the present day existence of pure Guaraní, but they seem to understand the term Jopará differently, including negative interpretations of the term. Galeano's criticism of the use of Jopará in the Ministry's textbook is a prime example. This discrepancy in opinion between policy makers and intellectuals may cause confusion and disrupt its implementation. It is thus encouraged to engage policy makers and intellectuals in policy dialogue so that they can agree upon the standardization of Jopará and a language-of-instruction-policy for an adequate implementation of Guaraní-Spanish bilingual education.

\section{Discussion}

I have just suggested proper training of bilingual teachers as one way to diminish the ideological and attitudinal gaps between the policy and operational levels of education. What else might be done to bridge the gaps and promote an effective language policy and its application? De Bres (2008) has explored this question in similar linguistic circumstances. He suggests what he calls "planning for tolerability," promoting positive attitudes towards minority languages among non-minority/majority language speakers through language policies, initiatives, programs, projects, and campaigns (e.g., bilingual education, television, signs, websites). He examined New Zealand, Wales, and Catalonia. Paraguay's case has some similarities to each of them: New Zealand in that both Guaraní and Maori are indigenous languages, Wales in that neither Paraguay nor Wales has ethnicity as the central problem of tolerability because both populations are rather "homogeneous," and Catalonia in that both Catalan and Guaraní are atypical minority languages spoken by the majority of Catalonians and Paraguayans respectively.

In terms of the increase of minority language speakers, the most successful case seems to be Wales. The number of Welsh speakers increased to 20.8 percent in 2001, compared to 18.7 percent in 1991 (Welsh Language Board 2010). The Welsh government, along with other stakeholders, has been making efforts to revive their language through promoting Welsh language rights, developing Welsh-media, and increasing the teaching of Welsh in school. Could the Welsh language policy be applied to Paraguay? In order to do so, there are several issues to be considered. First, it is doubtful whether Paraguay possesses the financial and technical resources available in Wales. The quality of Paraguay's bilingual education, for example, may be lower than that of Wales, and it may not be reasonably possible to simulate the same system in the near future. Second, the populations targeted for enhancing tolerability are different in these two countries. In Wales, the target population for enhancing tolerability is non-Welsh speakers (non-minority language speakers) who account for close to $80 \%$ of the Welsh population. In Paraguay, on the other hand, the target population is Guaraní speakers (minority language speakers), who account for over $80 \%$ of the Paraguayan population. What would be the implications of these differences? In that the target is the minority language speakers who are demographically dominant, Paraguay's case is more similar to Catalonia's. However, have Catalonia's policy initiatives been successful? The number of Catalan speakers has not increased. Yet, is the increase (or decrease) of the minority language speakers the only indicator to measure the change of language attitudes? Third, the Welsh language policy in promoting positive attitudes towards Welsh seems to have been implemented through enhancing integrative value of Welsh rather than its instrumental value. Could we promote Guaraní-Spanish bilingual education by further enhancing the integrative value of Guaraní that has already been well recognized as a national symbol and identity?

These arguments illustrate the dilemmas of sociolinguists but also showcase our strengths. We must debate both integrative and instrumental values of languages, balance realistic and idealistic measures, and take specific and comprehensive approaches to address the issues of preservation and/or promotion of minority languages. I 
argue that Guaranís instrumental value, while overshadowed by that of Spanish, is in urgent need of revisiting to truly see Paraguay's potential for human capital through to its realization. However, as in the case of Wales, promotion of a language's instrumental value is not the only means to an effective bilingual education. Ultimately, it is the ends, more than the means, which I seek to promote and to see achieved in Paraguay.

\section{Endnotes}

'Paraguay's Constitution, approved in 1992, includes Article 77 that stipulates the mandatory official native language education: "The teaching at the beginning of the schooling process will be in the official mother tongue of the student. Students will be taught to acknowledge and to use both official languages of the Republic." Also included is Article 140 that recognizes both Guaraní and Spanish as the official languages of Paraguay: "Paraguay is a bilingual and multicultural country. The official languages are Spanish and Guaraní. The law will establish the modalities of the use of one and the other" (Republic of Paraguay 1992).

${ }^{\mathrm{b}}$ According to the National Population and Housing Census, approximately $60 \%$ of the population primarily speaks Guaraní at home (Dirección General de Estadística, Encuestas y Censos 2002).

${ }^{\mathrm{C}}$ The concept of diglossia was first introduced by Ferguson (1959), who defines it as a type of bilingual situation in which two varieties of dialects coexist: the language of high variety $(\mathrm{H})$, which is usually the primary or standard dialect and the language of low variety (L), which is the secondary or non-standard dialect. Ferguson identifies $\mathrm{H}$ and $\mathrm{L}$ according to the degree of formality: while $\mathrm{L}$ is used by communities for ordinary conversation, $\mathrm{H}$ is largely learned through formal education. Fishman (1967) extended Ferguson's definition of diglossia to include bilingual and multilingual situations in which $\mathrm{H}$ and $\mathrm{L}$ are not genetically related. He also introduced the concept of domains, later called the domain analysis, to systematically explain bilingualism with the state of diglossia.

${ }^{d}$ These schools are located in the city of San Lorenzo, about seven miles away from Asunción, and the city of Capiata, 10-15 miles from Asunción. Central is generally Spanish dominant, though it largely depends on the area. These schools were selected because one of my Paraguayan friends is a Guaraní teacher in two of the three schools, and her son goes to the other.

'These schools are located in San Joaquín, a rural town, and a neighboring community called Virgen del Carmen. San Joaquín is located approximately 130 miles away from Asunción. There are no direct buses between San Joaquín and Asunción. The town is connected to the capital via two buses per day to Colonel Oviedo, and four buses from the city of Caaguazú, the nearest cities to San Joaquín. The distance between San Joaquín and these cities is about 45 miles. These schools were selected because I lived in Virgen del Carmen and worked in San Joaquín between 2004 and 2007.

${ }^{\mathrm{f}}$ During this period, I worked as community development officer for the Japan International Cooperation Agency and had approximately 70 colleagues in different parts of Paraguay. With the collaboration of my colleagues, I was able to administer questionnaires to 5,452 individuals, and drew data from the following nine of seventeen Paraguayan departments: Central, Caaguazú, San Pedro, Concepcion, Boqueron, Alto Parana, Itapua, Misiones, and Presidente Hayes.

${ }^{g}$ As described in Section 2, Guaraní has had a system of writing since the late $16^{\text {th }}$ century but has experienced some complications in actual practice. For instance, in major newspapers in Paraguay such as $A B C$ Color, Ultima Hora, Nación, Populár, and Crónica, Guaraní is hardly ever used except in individual names. Populár and Crónica more closely resemble tabloids and use Guaraní most among these five, but the articles are mostly written in Spanish with some common expressions in Guaraní. Rodríguez told me that Crónica used to use more Guaraní before, but the readers complained that Guaraní was more difficult to read than Spanish.

hIn this paper, "pure Guaraní" is defined as Guaraní that is used in academic contexts only (but not used daily by average citizens), while Jopará is defined as a language based primarily on Guaraní that utilizes a fair amount of Spanish loan words or phrases.

\section{Competing interests}

The author declares that he has no competing interests.

\section{Acknowledgement}

I am very fortunate to have a number of wonderful intellectuals around me and deeply grateful for their assistance in writing this paper. My appreciation for my academic advisors Professor Carlos A. Torres and Professor Concepcion M. Valadez is beyond description. They have offered insightful comments, constant guide and heartful encouragement even after my graduation from University of California, Los Angeles. I would also like to thank my excellent editors Mr. Ezra Anton Greene and Dr. Amanda Kenderes. It would not have been possible to publish this paper without their support.

Received: 20 June 2012 Accepted: 4 September 2012

Published: 3 October 2012

\section{References}

Baker, C. 2006. Foundations of Bilingual Education and Bilingualism. Clevedon: Multilingual Matters

Benson, CJ. 2002. Real and Potential Benefits of Bilingual Programmes in Developing Countries. International Journal of Bilingual Education and Bilingualism 5(6): 303-317.

Brisk, ME. 2006. Bilingual Education From Compensatory to Quality Schooling. Mahwah, NJ: Lawrence Erbaum Associates Associates.

Bühmann, D, and B Trudell. 2008. Mother Tonque Matters: Local Language as a Key to Effective Learning. Paris: UNESCO.

Caballero, VC. 2008. When Policy becomes Practice: Teachers' Perspective on Official Bilingualism and the teaching of Guaraní as a Second Language. PhD diss.: Arizona State University.

Centurión, MR. 2004. Debido Proceso y Desarrollo. Asunción: SERVILIBRO. 
Choi, JK. 2005. Bilingualism in Paraguay: Forty years after Rubin's study. J Multiling Multicult Dev 26(3): 233-248.

Cooney, JW. 1983. Repression to Reform: Education in the Republic of Paraguay, 1811-1850. History of Education Quartely 23(4): 413-428.

Corvalán, G. 1989. Política lingüística y educación. Asunción: Centro Paraguayo de Estudios Sociolingüisticos

Corvalán, G. 2005. La vitalidad de la lengua guaraní en el Paraguay. Población y Desarrollo 30: 9-27.

Cummins, J. 2009. Bilingual and immersion programs. In The Hand Book of Second Language Teaching, ed. M Long and CJ Doughty. Oxford: WileyBlackwell.

Cummins, J, and S Schecter. 2003. Multilingual in Practices: Using Diversity as a Resource. Portsmouth, $\mathrm{NH}$ : Heinemann.

De Bres, J. 2008. Planning for tolerability in New Zealand, Wales and Catalonia. Current Issues in Language Planning 9(4): 464-482.

Dirección General de Estadística, Encuestas y Censos. 2002. Censo Nacional de Población y Viviendas, Dirección General de Estadística, Encuestas y Censos.

Engelbrecht, G, and L Ortiz. 1983. Guaraní Literacy in Paraguay:: The National Institute of Education to the University of New Mexico.

Ferguson, CA. 1959. Diglossia. Word 15: 325-340.

Fishman, JA. 1967. Bilingualism with and without Diglossia; Diglossia with and without Bilingualism. J Soc Issues 23: 29-38.

Fogelquist, DF. 1950. The bilingualism of Paraguay. Hispania 33(1): 23-27.

Galeano, DA. 2002. Antropología Avakuaaty. Asunción: Serie Ateneo de Lengua y Cultura Guaraní.

García, P. 2005. Case study: Parental language attitudes and practices to socialize children in a Diglossic Socity. The International Journal of Bilingual Education and Bilingualism 8(4): 328-344.

García, O. 2011. Bilingual Education in the $21^{\text {st }}$ Century: A global perspective. Oxford: Wiley Blackkwell.

Gómez, G. 2006. El Plurilingüismo Paraguayo. Asunción: SERVILIBRO.

Gómez, G. 2007. La Lengua Vernácula en el Proceso Sociohistórico del Paraguay. Asunción: SELVILIBRO.

Gynan, SN. 1999. Post-Stroessner language planning in Paraguay. http://myweb. facstaff.wwu.edu/sngynan/f99paper.html Accessed 26 April 2012.

Gynan, SN. 2005. Official bilingualism in Paraguay, 1995-2001: An analysis of the impact of language policy on attitudinal change. http://www.lingref.com/ cpp/wss/2/paper1138.pdf Accessed 23 April 2012.

Gynan, SN. 2007. Language planning and policy in Paraguay. In Language Planning and Policy in Latin America, Vol. 1 Ecuador, Mexico and Paraguay, ed. RB Baldauf Jr and RB Kaplan, 218-283. Clevedon: Multilingual Matters.

Hauck, JD. 2009. Language Under Construction: Bilingualism in Paraguay and Some Unsettled Thoughts about Language. Berlin: WeiBenser Verlag.

He, AE. 2012. Systematic use of mother tongue as learning/teaching resources in target language instruction. Multiling Educ 2(1): 15.

Hudson, A. 2002. Outline of a theory of diglossia. Int J Sociol Lang 157: 1-48.

Ito, H. 2010. The Role of Guarnai in Paraguay's National Development: Critical Deconstruction of Language Ideology. Los Angeles: PhD diss., University of California.

Japan International Cooperation Agency. 2004. Final Report on Paraguay's Education Sector Research and Analysis. Asunción: Japan International Cooperation Agency.

López, LE. 2010. 2009. Reaching the unreached: indigenous intercultural bilingual education in Latin America. Background paper prepared for the EFA Global Monitoring Report.

May, S. 2008. Language education, pluralism and citizenship. In Encyclopedia of Language and Education, Language Policy and Political Issues in Education, vol. 1, 2nd ed, ed. S May and N Hornberger, 15-29. New York: Springer.

Mortimer, K. 2006. Guaraní académico or Jopará? Educator perspective and ideological debate in Paraguayan bilingual education. Working Papers in Educational Linguistics 21(2): 45-71.

Peralta, N, P Misiego, and J Prieto. 2011. Informe de la Investigación: Deserción en la Educación. MEC: Centro de Investigación e Innovación Educativas.

Pic-Gillard, C. 2004. Incidencias Sociolingüistics del Plan de Educación Bilingüe Paraguayo 1994-1999. Asunción: SERVILIBRO.

Republic of Paraguay. 1967. Constitución de la República del Paraguay. Asunción: Republic of Paraguay.

Republic of Paraguay. 1992. Constitución de la República del Paraguay. Asunción: Republic of Paraguay.

Rubin, J. 1968. National Bilingualism in Paraguay. Asunción: Mouton and Company.
Ruíz, R. 1984. Orientations in Language Planning. NABE Journal 8(2): 15-34. Truedell, B. 2012. Of gateways and gatekeepers: Language, education and mobility in francophone Africa. Int J Educ Dev 32: 368-375.

Tse, L. 2001. Why don't They Learn English? Teachers College. The Hague: Columbia University Press.

UNESCO. 2011. EFA Global Monitoring Report 2011 - The hidden crisis. New York: UNESCO.

Valadez, CM. 2002. Education systems and language policies in California and Paraguay: Promoting or repressing bilingualism? A paper presented to the Second International Symposium on Bilingualism. Galicia, Spain: University of Vigo.

Villagra-Batoux, SD. 2002. El Guaraní Paraguayo. Paris: EXPOLIBRO.

Welsh Language Board. 2012. The 2001 Census. http://www.webarchive.org.uk/ wayback/archive/20120330005030/http://www.byig-wlb.org.uk/English/ welshlanguage/Pages/WhoaretheWelshspeakersWheredotheylive.aspx Accessed 24 August 2012.

Wiley, TG. 2005. Literacy and Language Diversity in the United States. Asunción: The Center for Applied Linguistics.

Wright, L. 2004. Language and value: Towards accepting a richer linguistic ecology for South Africa. http://eprints.ru.ac.za/1181/1/Language_and_value_ (Regan_ed.).pdf Accessed 23 April 2012.

\section{doi:10.1186/2191-5059-2-6}

Cite this article as: Ito: With Spanish, Guaraní lives: a sociolinguistic analysis of bilingual education in Paraguay. Multilingual Education 2012 2:6.

\section{Submit your manuscript to a SpringerOpen ${ }^{\odot}$ journal and benefit from:}

- Convenient online submission

- Rigorous peer review

- Immediate publication on acceptance

- Open access: articles freely available online

- High visibility within the field

- Retaining the copyright to your article

Submit your next manuscript at springeropen.com 